\title{
Spirituality at the workplace and its role on organizational justice
}

\author{
Jamshid Salehi Sadaghiani $^{\mathrm{a}}$, Jafar Beikzad ${ }^{\mathrm{b}}$, Sackine jafary ${ }^{\mathrm{b}}$ and Saeid Ghorbannejad Maleki ${ }^{\mathrm{b}}$
}

${ }^{a}$ Department of Management, Allameh TabaTabayi University Tehran, Iran

${ }^{b}$ Department of Public Management, Islamic Azad University, Bonab branch, Bonab, Iran

\begin{tabular}{|c|c|}
\hline A R T I C L E I N F O & A B S T RA C T \\
\hline $\begin{array}{l}\text { Article history: } \\
\text { Received April 15, } 2011 \\
\text { Received in Revised form } \\
\text { July, } 19,2011 \\
\text { Accepted } 21 \text { July } 2011 \\
\text { Available online } \\
24 \text { July } 2011 \\
\text { Keywords: } \\
\text { Spirituality } \\
\text { Working environment }\end{array}$ & $\begin{array}{l}\text { Spirituality and ethics play important roles in bringing justice for many business units. During } \\
\text { the past few years, there has been growing concern on thinking about profitability without } \\
\text { considering other aspects such as spirituality. The infamous Enron incident has been a crystal } \\
\text { clear of a case of thinking just on short-term profitability without considering other ethical } \\
\text { issues. Spirituality helps organizations create ethical values, responsibility and job satisfaction } \\
\text { among workers and these issues could increase business competitive advantages. In this paper, } \\
\text { we study the impact of spirituality on different levels of individual, workspace and } \\
\text { organizational for a real-world case study. The survey results of this paper indicate that } \\
\text { spirituality could significantly impact the organization in different levels. }\end{array}$ \\
\hline
\end{tabular}

Efficiency

Competition

\section{Introduction}

During the past few years, there has been growing interest in studying the impact of spirituality in working environments (McCormick, 1994; Rifkin, 1995; Mitroff \& Denton, 1999; Gibbons, 1999; Gibbons, 2002; Rojas, 2002). The idea is that many business units would not have failed had they believed to strong sense of spirituality in their working environment. The infamous incident of Enron has created tremendous motivation on paying more attention on spirituality among workers. There have been many theoretical models to study how spirituality could contribute to working environments.

Ashmos and Duchon (2000) proposed a model of a theory of spiritually-informed management, which integrated traditional and spiritual approaches to management. Their model consisted of three parts of awareness, which includes unconsciousness and consciousness, change, which incorporates translation and transformation. The third part of the model is manifestation, which cover temporal and perennial.

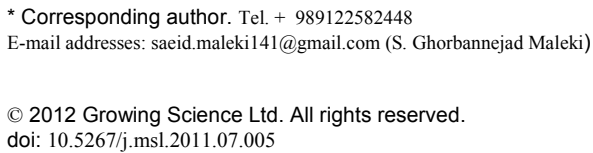


Bradley and Kauanui (2003) compared spirituality on three southern California college campuses. They studied the spirituality of professors and the spiritual culture found in a private secular college, a private Christian college and a state university, all located in southern California. The results indicated that there was a difference in the spiritual culture between these three campuses and that the spirituality of the professors was a reflection of the spiritual culture found on the campuses. Colquitt et al. (2001) reviewed of 25 years of organizational justice research.

Spirituality and religion in work (SRW) has been gaining interest in the popular press for a long time and it has recently been recognized in the field of academic community. Fornaciari and Lund Dean (2001) explored the tension between relevance and legitimacy, focusing on research methods, models, and traditions that may serve both well. They explained that many ideas that support such work already exist, discussed some of them, and provided operational blueprints for alternative forms of excellent research. They argued that combining such methodological underpinnings allows the scholarly work to emerge.

Kinjerski and Skrypnek (2004) identified organizational factors that foster an individual's experience of spirit at work. They interviewed ten women and three men in different ages who were full-time employee in a variety of occupations with self-identified as having high spirit at work. They concluded that leadership emerged as central to influencing individual experiences of spirit at work and it was strongly linked to other organizational factors. Krishnakumar and Neck (2002) studied about the meaning of term "spirituality" and explained the multiple views of workplace spirituality. They argued that there could be different definitions for the meaning of "spirituality" because of the very strong personal nature of the word itself and explained that this multiple view of spirituality was a positive thing for organizations if managers attempt to understand differing spiritual views and they are interested in different views within an organization.

Kidder (2007) explored the concept of restorative justice as a tool for rebuilding trust and repairing damaged relationships in the workplace. Kidder recommended that the objectives of restorative justice are to repair the harm after a damaging accident, to repair the damaged relationship between the two parties in conflict, and to recover the offender back to the community.

Sendjaya (2007) studied the development and validation of a spiritual leadership measure in three stages. In the first stage, Sendjaya built content validity into the measure through content analysis of interview data, extant literature review, and content expert item analysis. In the second stage, Sendjaya established reliability and preliminary construct validity based on the confirmatory factor analysis of pre-test data. In the final stage, Sendjaya validated the results through cross-validation in a new sample. The resulting four-item spiritual leadership scale somewhat showed robust preliminary psychometric properties.

According to Mitroff and Denton (1999) an increasing number of business leaders have reportedly been relying on their religious beliefs, values, and practices for business solutions and leadership approaches. Nadiri and Tanova (2010) performed an investigation of the role of justice in turnover intentions, job satisfaction, and organizational citizenship behavior in hospitality industry.

Neal (1997) and Neal and Biberman (2003) discussed three major forces, which leads to an increasing interest in spirituality in industrialized countries: baby-boomers coming of age, turbulent changes in organizations, and the approach of the millennium. They explored spirituality in the workplace and provided an annotated bibliography and other resources connected with the field. The research also offered five guidelines for teaching management education from a spiritual perspective, namely know thyself, act with authenticity and congruency, respect and honor the beliefs of others, be as trusting as you can be, and maintain a spiritual practice. Staley et al. (2003) investigated the contribution of organizational justice in budget decision making to federal managers organizational commitment. 
In this paper, we study the impact of spirituality in working environment of a power plant organization located in west part of Iran. The business unit called Sahand located near the city of Tabriz, which is one of industrialized cities of the country. We present the details of our survey in section 2, discuss the results in section 3 and concluding remarks are given at the end to summarize the contribution of the paper.

\section{The proposed study}

The proposed study of this paper uses the method described in Ashmos et al. (2000) to design the sampling data. Therefore, In order to find out the number of sample size we have used the following statistical sampling technique,

$$
n=\frac{N \times z_{\alpha / 2}^{2} \times p \times q}{\varepsilon^{2} \times(N-1)+z_{\alpha / 2}^{2} \times p \times q},
$$

where $N$ is the population size, $p=1-q$ represents the yes/no categories, $z_{\alpha / 2}$ is CDF of normal distribution and finally $\varepsilon$ is the error term. Since we have $p=0.5, z_{\alpha / 2}=1.96$ and $N=272$, the number of sample size is calculated as $n=161$. The questionnaire was designed based on the work proposed by Niehoff and Moorman (1993). There were five questions about organizational justice, spirituality at work, workspace spirituality at individual level and workspace spirituality at organizational level.

The primary question of the survey was to see whether spirituality has any impact on organizational justice in Sahand power plant working environment. The question consists of the following three sub questions. The first question studies whether individual level workspace spirituality has any impact on organizational justice for the case study of our paper.

The second question concerns on divisional level work space spirituality effects on organizational justice and the last question is whether organizational level work space spirituality influence organizational justice for the case study of this paper. We use various statistical tests to find appropriate replies for the questions of this paper in the next section.

\section{The results}

As we explained earlier, we have distributed the questionnaire and the data were gathered and analyzed. The Chronbach Alpha coefficient was 0.932, which means the questionnaire maintains a high reliability. Table 1 summarizes the results of our survey on the first five questions. As we can observe there are strong correlation among all questions.

\section{Table 1}

The statistical results of questions of the survey

\begin{tabular}{llll}
\hline Variable & Average & Standard derivation & Pierson's correlation \\
\hline Organizational justice & 62.345 & 16.090 & 0.000 \\
Spirituality at work & 315.198 & 36.971 & 0.602 \\
Work space spirituality at individual level & 173.267 & 16.621 & 0.339 \\
Work space spirituality at divisional level & 71.583 & 21.847 & 0.610 \\
Work space spirituality at organizational level & 70.347 & 13.736 & 0.638 \\
\hline
\end{tabular}

Next, we have also performed a simple regression analysis between spirituality at work and other levels of spirituality. Table 2 summarizes the results of our survey where $\beta$ is the slope of the regression, $\mathrm{t}$-student and $\mathrm{p}$-value for all regressions. 
Table 2

The statistical results of regression analysis of the survey

\begin{tabular}{llll}
\hline Variable & $\beta$ & t-student & p-value \\
\hline Spirituality at work & 0.262 & 9.497 & 0.000 \\
Work space spirituality at individual level & 0.328 & 4.545 & 0.000 \\
Work space spirituality at divisional level & 0.764 & 9.708 & 0.000 \\
Work space spirituality at organizational level & 0.748 & 10.458 & 0.000 \\
\hline
\end{tabular}

As we can observe from Table 2, all t-students are well above 2.6 and p-values are meaningful. In addition, the F-value for four regression tests are 90.201, 20.659, 94.245 and 109.376, respectively. Therefore, we can conclude that spirituality could significantly contribute on different individual, divisional and organizational levels.

We have also interviewed people who participated in our survey to see how they feel about the impact of spirituality in their working environment in terms of bringing more commitments to contribute to their working environment. They mostly claimed that there must be some regulation to remove spirituality obstacles at working environment. The believed spirituality plays an important role on encouraging them to do their works more precisely and accurately. They also claimed people with more faith on spirituality feel more responsible on doing their jobs, which brings more fidelity to company's values.

The following recommendations made for improving the spirituality and achieving organizational justice in our case study,

- Fair evaluation of work,

- Encouraging people to accept legitimate risk,

- Creating more enjoyable working conditions,

- Removing any discrimination feeling in workplace,

- Removing any obstacle for people to practice spirituality,

- Building constructive relationships among workers in different levels,

- Building an environment for people to feel more faithful to company's resolutions,

- Encouraging people to learn more,

- Taking care of workers' health conditions,

- Creating an honest working environment,

- Familiarizing workers with company's rules and regulations,

- Providing facilities for getting feedbacks from people,

- Encouraging people to learn more,

- Providing a worship place.

\section{Conclusion}

In this paper, we have presented an empirical study to learn the effects of spirituality in different levels of individual, divisional and organizational. The study selected a sample size of 161 people out of a population of 272 who worked for a power plant unit. The results of our survey clearly indicated that spirituality performs a significant contribution on working performance in all different levels. The results indicated that there is a strong correlation among spirituality at work and different levels of spirituality. The results of in dept interview with the people who participated in our survey also revealed that people with more faith on spirituality feel more responsible on doing their jobs, which brings more fidelity to company's values. 


\section{Acknowledgment}

The authors would like to thank the anonymous referees for their constructive comments on earlier version of this work.

\section{References}

Ashmos, D., Ashmos, D.P., \& Duchon, D. (2000). Spirituality at work: A conceptualization and measure. Journal of Management Inquiry, 9(1), 134-145.

Ashmos, D.P., \& Duchon, D. (2000). Spirituality at work: a conceptualization and measure. Journal of Management Inquiry, 9(2), 134-145.

Bradley, J \& Kauanui, S. K. (2003). Comparing spirituality on three southern California college campuses. Journal of Organizational Change Management, 16(4), 448 - 462.

Colquitt, J.A., Conlon, D.E., Wesson, M.J., Porter, C.O.L.H., \& Ng, K.Y. (2001) Justice at the millennium: A. Meta analytic review of 25 years of Organizational Justice Research. Journal of Applied Psychology, 86, 425-445.

Fornaciari, C., \& Lund Dean, K. (2001). Making the quantum leap: lessons from physics on studying spirituality and religion in organizations. Journal of Organizational Change Management, 14(4), 335-51.

Gibbons, P. (1999). Spirituality at Work: A Pre-Theoretical Overview, MSC. Thesis - Birnbeck Callege, University of London.

Gibbons, P. (2002). Spirituality at work: Definitions, measures, assumptions, and validity claims. Paper presented at the academy of management annual meetings, Toronto.

Hinnells, J. R. (1995). A New Dictionary of Religions. Oxford: Blackwell.

Kinjerski, V. M. \& Skrypnek, B. J. (2004). Defining Spirit at Work: Finding Common Ground. Journal of Organizational Change Management, 17(1), 26-42.

Krishnakumar, S. \& Neck, C. P. (2002). The "what", "why" and "how" of spirituality in the workplace. Journal of Managerial Psychology, 17(3), 153-164.

Kidder, D. L. (2007). Restorative justice: not "rights", but the right way to heal relationships at work. International Journal of Conflict Management, 18(1), 4-22.

McCormick, D (1994). Spirituality and management. Journal of Managerial Psychology, 9(6), 5-8.

Mitroff, I. \& Denton, E. (1999). A Spiritual Audit of Corporate America: A Hard Look at Spirituality, Religion, and Values in the Workplace. Jossey - Bass, San Francisco, CA.

Mitroff, I. L., \& Denton, A. E. (1999). A Study of Spirituality in the Workplace. Journal Sloan Management Review, 40(4), 83-92.

Myers, J. E. (1990). Wellness throughout the lifespan. Guidepost, 23, 11-11.

Nadiri, H., \& Tanova, C. (2010). An investigation of the role of justice in turnover intentions, job satisfaction, and organizational citizenship behavior in hospitality industry. International Journal of Hospitality Management, 29, 33-41.

Neal J. A (1997). Spirituality in management education: a guide to resources. Journal of Management Education, 21(1), 121-139.

Neal, J., \& Biberman, J. (2003). Introduction: the leading edge in research on spirituality and organizations. Journal of Organizational Change Management, 16(4), 363-366.

Niehoff, B. P. \& Moorman, R. H. (1993). Justice as a mediator of the relationship between methods of monitoring and organizational citizenship behavior. Academy of Management Journal, 36, 527556.

Rojas, R. (2002). Management Theory and Spirituality: A Framework and Validation of the Independent Spirituality Assessment Scale, DBA, Dissertation, Argosy University / Sararota.

Rifkin, J. (1995). The end of work: Technology, Job and Your Future, New York: Putman. 
Staley, A.B., Dastoor, B., Magner, N.R, \& Stolp, C. (2003). The contribution of organizational justice in budget decision making to federal managers organizational commitment. Journal of public budgeting, accounting \& financial management, 15(4), No.4, 505-515.

Sendjaya, S. (2007). Conceptualizing and measuring spiritual leadership in organizations. International Journal of Business and Information, 2(1), 104-126. 